\title{
Editorial
}

Published online: February 10, 2006

DOI: $10.1159 / 000091450$

\section{Is the Type of Hemodialysis Important to Control Serum Phosphate?}

\author{
Luca De Nicola Roberto Minutolo Giuseppe Conte \\ Chair of Nephrology, Second University of Naples, Naples, Italy
}

A high serum phosphate $(\mathrm{P})$ level is an independent determinant of morbidity and mortality in hemodialysis (HD) patients, with values of $\leq 4.5 \mathrm{mg} / \mathrm{dl}$ to be considered as the ideal target [1, 2]. To date, however, the therapeutic interventions have generally failed with about $50 \%$ of patients showing predialytic $\mathrm{p}$ values $>5.5 \mathrm{mg} / \mathrm{dl}$ $[2,3]$.

Prevention of hyperphosphatemia is based on restriction of dietary $\mathrm{P}$ intake and reduction of intestinal absorption of $\mathrm{P}$; however, both the therapeutic approaches are weakened by major drawbacks. Indeed, lowering of protein intake $<1.0 \mathrm{~g} / \mathrm{kg}$ b.w./day to reduce dietary $\mathrm{P}$ is not safe since this is the minimum level to avoid malnutrition in HD patients; HD, in fact, induces protein catabolism by means of loss of amino acids and albumin, and by inflammatory stimuli as well. On the other hand, use of $\mathrm{P}$ binders to decrease absorption may be associated with detrimental effects dependent on excessive load of aluminum or calcium; a more valid alternative is likely represented by the new generation of calcium and aluminum-free agents but compliance to prescription is often hardly achieved for these drugs.

On the basis of these observations, the role of dialytic removal in the achievement of adequate $\mathrm{P}$ levels becomes relevant. Standard 4-hour HD allows to remove about $800 \mathrm{mg} / \mathrm{session}$, that is, $2,500 \mathrm{mg}$ in 1 week. This amount is almost half of the quantity of $\mathrm{P}$ derived from a normal protein intake. Therefore, standard intermittent HD is not efficacious if not associated with dietary restriction and $\mathrm{P}$ binders.

In this issue of Blood Purification, Bolasco et al. compared P kinetics in standard HD and on-line hemodiafiltration with endogenous reinfusion (HFR) by using a new method to measure $\mathrm{P}$ levels into the dialysate. This issue is of interest because sensitivity of the common automatic analyzers is inadequate to precisely quantify the low $\mathrm{P}$ concentrations into the dialysate. Nevertheless, from the clinical point of view, the most important finding of the study is that the dialytic P removal by HFR was comparable to that obtained by standard HD, and that both types of dialysis allowed to maintain the plasma $\mathrm{P}$ levels below the recommended target in most patients [4]. However, HFR also decreases inflammatory stimuli because of purity of reinfusion solution, adsorption of inflammatory cytokines by resin and optimal balance of bicarbonate [5]. This point is critical; in fact in uremic patients, inflammation and metabolic acidosis worsens nutritional status. Taken together, these findings suggest that HFR may be an option more suitable than standard HD to ameliorate $\mathrm{P}$ balance in the subset of patients with impaired nutritional status or signs of systemic inflammation. Long-term controlled studies on this issue are still required to verify this hypothesis.

Of note, standard hemodiafiltration techniques (HDF), where ultrafiltrate is not reinfused, significantly increase $\mathrm{P}$ removal, of about $40 \%$ versus HD, because of

\section{KARGER \\ Fax +4161306 1234 E-Mail karger@karger.ch} www.karger.com
(C) 2006 S. Karger AG, Basel 0253-5068/06/0243-0299\$23.50/0

Accessible online at: www.karger.com/bpu
Prof. Luca De Nicola

Via S.A. Capodimonte, 46, P.co Villa Teresa, lotto 30

IT-80131 Naples (Italy)

Tel./Fax +390812549409

E-Mailluca.denicola@unina2.it 
the greater convective removal of $\mathrm{P}[6,7]$. HDF has been found effective in significantly improving $\mathrm{P}$ levels also in the medium term [7]. It is important to note, however, that HFR, as compared with HDF, induces a minor loss of amino acids into dialysate, leading to higher levels of amino acids in plasma [8]. This finding suggests a minor risk of malnutrition for HFR with respect to HDF that, again, must be confirmed in studies with adequate followup.

Finally, as evidenced in chronic studies $[9,10], \mathrm{P}$ removal can also be improved by prolonging duration or frequency of dialytic sessions; in fact the consequent increase of weekly dialytic dose drastically improves control of $\mathrm{P}$ levels with patients that are allowed to discontinue $\mathrm{P}$ binders and ingest a more liberal diet.

In conclusion, the type of dialytic treatment plays a major role in the control of phosphatemia in uremic patients. HFR is a suitable option to control serum P, especially in patients at risk of malnutrition and/or inflammation. However, at variance with standard HDF and prolonged or more frequent HD sessions, controlled studies are required to confirm these effects in the long term.

\section{References}

1 Slinin Y, Foley RN, Collins AJ: Calcium, phosphorus, parathyroid hormone, and cardiovascular disease in hemodialysis patients: the USRDS waves 1, 3, and 4 study. J Am Soc Nephrol 2005;16:1788-1793.

2 Young EW, Albert JA, Satayathum S, et al: Predictors and consequences of altered mineral metabolism among hemodialysis patients in the Dialysis Outcomes and Practice Patterns (DOPPS) study. Kidney Int 2005;67:1-9.

3 Block GA, Hulbert-Shearon TE, Levin NW, Port FK: Association of serum phosphorous and calcium $\times$ phosphate product with mortality risk in chronic hemodialysis patients. A national study. Am J Kidney Dis 1998;31: 607-617.
4 Bolasco PG, Ghezzi PM, Ferrara R, et al: New method for the phosphate kinetics estimation during hemodialysis and on-line hemodiafiltration with endogenous reinfusion. Blood $\mathrm{Pu}$ rif 2006;24:301-308.

5 De Francisco AL, Botella J, Escallada R, et al: Hemodiafiltration with sorbent-regenerated ultrafiltrate as replacement fluid: a multicenter study. Nephrol Dial Transplant 1997;12:528534.

6 Zehnder C, Gutzwiller JP, Renggli K: Hemodiafiltration, a new treatment option for hyperphosphatemia in hemodialysis patients. Clin Nephrol 1999;3:152-159.
7 Minutolo R, Bellizzi V, Cioffi M, et al: Postdialytic rebound of serum phosphorus: pathogenetic and clinical insights. J Am Soc Nephrol 2002;13:1046-1054.

8 Ghezzi PM: Hemodiafiltration with endogenous reinfusion. G Ital Nefrol 2004;21(suppl 30):S23-S28

9 Mucsi I, Hercz G, Uldall R, et al: Control of serum phosphate without any phosphate binders in patients treated with nocturnal hemodialysis. Kidney Int 1998;53:1399-1404.

10 Locatelli F, Buoncristiani U, Canaud B, Köhler H, Petitclere T, Zucchelli P: Dialysis dose and frequency. Nephrol Dial Transplant 2005;20: 285-296. 